\title{
The Effect Of Brand Identification And Self-Concept Connection On Brand Love And Its Implications For Brand Loyalty
}

\author{
Devi Dwi Agusthera1) \\ dwiagusthera@gmail.com \\ Theresia Militina2) \\ theresia.militina@feb.unmul.ac.id \\ Saida Zainurrosalamia ZA ${ }^{3}$ ) \\ saida.zainurosalamia.za@ feb.unmul.ac.id \\ 1)Magister of Management, Faculty of Economics and Business, Mulawarman \\ University, Samarinda. \\ 2,3)Faculty of Economics and Business, Mulawarman University, Samarinda.
}

\begin{abstract}
This study aims to analyze and find out Brand Identification, Self-Concept Connection, Brand Love and Brand Loyalty for iPhone brand Smartphone users in Samarinda. The background of this research refers to the relationship between Brand Identification and Self-Concept Connection that is woven by the iPhone Brand with its users. Besides seeing how the Brand Identification and Self-Concept Connection formed the Brand Love and Brand Loyalty iPhone smartphone users in Samarinda. Brand Identification and Self-Concept Connection may not necessarily create optimal love for iPhone smartphone users in Samarinda, so it needs to be reevaluated along with how much influence it has on brand loyalty. This research is a quantitative descriptive study and uses SEM-AMOS v.22, analysis tool with the SAMPLE formula $=\Sigma$ Indicator $\times(5-10)$, which then selected samples of 102 respondents. Data collection techniques using the proportional accidental sampling method. The results showed that five proposed hypotheses were accepted namely Brand Identification had a significant effect on Brand Love, Self-Concept Connection had a significant effect on Brand Love, Brand Identification had a significant effect on Brand Loyalty, Self-Concept Connection had a significant effect on Brand Loyalty and Brand Love had a significant effect towards Brand Loyalty. These findings support the theory and previous research that became the reference of researchers.
\end{abstract}

Keywords: brand identification; self-concept connection; brand love; brand loyalty 


\section{PRELIMINARY}

Customers who make repeat purchases on the marketed brand are a dream for marketers, given the loyalty they make will consistently contribute to the revenue and profits generated by the company, (Reichheld, Teal, \& Smith, 1996). In order for consumers to be loyal, companies use loyalty programs, such as giving customer gifts at certain moments (O'Brien \& Jones, 1995) or locking customers through product compatibility, such as post-sales services that are specifically served by brand holders, (Büschken, 2004).

The importance of understanding the desires of consumers has finally come to the attention of various industries, one of which is the telecommunications industry. Smartphone as a necessity, this is what is read by manufacturers companies that produce smartphones. Consumers themselves are the main key of the company in gaining profits and high market share, (Wijayanti, 2008), so it is not surprising that these companies are competing to provide satisfaction and the best quality through marketed products. This market share was created partly because of the satisfaction and trust that was created due to the effects of the use of these smartphone products. Consumer confidence in a brand will make consumers make purchases and consumers will feel very satisfied with the product purchased, so this can affect the formation of brand love (brand love) of the product. Love of the brand affects the occurrence of brand loyalty and positive word of mouth to various consumers.

Based on research conducted by (Clara, 2019), shows that the role of brand love as a mediating factor between customer satisfaction with brand loyalty and positive word of mouth can be proven where if the respondent has feelings of love or more than just liking because of the high satisfaction of the smartphone brand iPhone, then this will support the desire of respondents to spread positive words about the iPhone brand smartphone and create loyalty to the iPhone brand smartphone. Likewise with an action-assembly theory where the theory shows that consumer behavior in his experience using a product in giving rise to an action.

However, most researchers think that brand loyalty will get better when customers have very strong positive feelings towards the brand (Dick \& Basu, 1994), involve psychological conditions that bind customers to the brand (Kotler \& Keller, 2011), and strengthen the commitment to do repeat purchases, (Oliver, 1999).

Previous researchers have argued that consumers have experience with a brand when they are looking for the right product, make a purchase, and use it, (Arnould, Price, \& Zinkhan, 2002); (Brakus, Schmitt, \& Zarantonello, 2009). When their experience is positive, it is predicted consumers will be happy to buy back the brand.

A high level of brand loyalty helps influence the sale of a brand. Consumers who feel satisfaction will tell other consumers to buy the same brand product. A consumer who wishes to buy a smartphone will first seek information in advance, both about quality, brand, design, price, excellence and so on.

The phenomenon of consumer loyalty (brand loyalty) to the purchase of iPhone brand smartphone products previously influenced by the attitude of consumers who like the iPhone brand (brand love), this is because consumers feel attracted to new products that they know. Brand love is a degree of strong emotional desire that accompanies consumer satisfaction with certain brand names. (Carroll \& Ahuvia, 2006), states that after consumers consume and experience high levels of satisfaction that can affect consumers' love of brands, consumers will become more loyal to the 
brand or spread positive words about the brand to various parties. This assessment is called brand love.

Consumers have experience with certain brands when they are exposed to several stimuli associated with these brands, for example, colors (Meyers-Levy \& Peracchio, 1995), (Veryzer Jr \& Hutchinson, 1998), typeface used, (Mandel \& Johnson, 2002), (Keller, 1987), as well as when they are buying or consuming them, which underlies (Brakus et al., 2009), proposes the concept of brand experience and defines it as subjective responses (sensations, feelings, thoughts) and consumer behavior caused by stimuli associated with a brand in the form of design and identity (name, logo, packaging, and communication (brochures, websites), as well as its environment (shops that sell). (Brakus et al., 2009), operationalize the concept into 4 (four) dimensions, namely sensory (sensory), affective (affective), behavioral (behavioral), and intellectual (intellectual).

Technological developments, especially in the telecommunications industry in modern and global times are currently experiencing a large increase. All groups of people both from the bottom up to the top have used smartphones for a variety of purposes, both for business, family or other purposes. This development does not only occur in one area but also occurs in every side of human life. Improvement in the field of communication technology is very important to support daily needs, especially communication devices such as smartphones. Various brands and features added in smartphone products, one of which is the iPhone brand.

\section{METHOD}

The research instrument used in this study was a questionnaire instrument in the form of a questionnaire filled out by respondents to get responses regarding the relationship between Brand Identification (X1), Self-Concept Connection (X2), Brand Love (Y1) and Brand Loyalty (Y2) which experienced by iPhone brand smartphone users in Samarinda City. Regarding some indicators included in the questionnaire obtained through the results of literature studies.

Before becoming an instrument, it is necessary to test the instrument first and analyze it with validity and reliability tests. The validity test will be performed using the Karl Person product-moment correlation coefficient, while the reliability test will be carried out using the Cronbach Alpha coefficient. This analysis was carried out with the help of the SPSS program.

Descriptive statistics are used to provide an overview of the respondents' demographic data, knowing the absolute frequency distribution that shows the average, median, and standard deviation figures.

Analysis of the strength of relationships/influences between constructs, both direct, indirect and total relationships.

The direct effect is the coefficient of a line with one end of an arrow and occurs in two constructs directed by a line of one-way arrows.

Indirect effects (indirect effects) are effects that arise through an intermediate variable and occur in two constructs that are not addressed by a one-way arrow line.

The total effect (total effect) is the effect of a different relationship between the direct effect and the indirect effect. 


\section{RESULTS AND DISCUSSION}

The testing of the research instrument consisted of testing the validity of the criteria and the consistency of internal reliability. Validity is the accuracy or accuracy of an instrument in measuring what you want to be measured. In testing data collection instruments, factor validity is measured when items are arranged using more than one factor (the sum of items in one factor) with a total factor score (total factors), whereas measurement of item validity is by correlating between item scores and total item scores. So the instrument is said to be valid means to show the measuring instrument used to get the data is valid and can be used to measure what you want to study.

While reliability is a measuring tool that shows that the measuring instrument used in research which has reliability as a measuring tool, including measuring through the consistency of measurement results from time to time, reliability is useful to determine whether the instrument, in this case, is a questionnaire that can be used more than one time, at least by the same respondent will get a consistent answer. The results of testing the validity and reliability of a full research instrument can be seen in the appendix, in summary, can be seen in the following table:

\begin{tabular}{|c|c|c|c|c|c|}
\hline Table & results & for & validity & and & reliability \\
\hline Variable & Indicator & $\begin{array}{l}\text { Notatio } \\
\mathrm{n}\end{array}$ & $\begin{array}{l}\text { Koefisien } \\
\text { Korelasi } \\
(\mathrm{r}) \\
\end{array}$ & Validity & $\begin{array}{l}\text { Alpha } \\
\text { Cronbach } \\
\text { (Reabilitas) }\end{array}$ \\
\hline \multirow{4}{*}{$\begin{array}{l}\text { Brand } \\
\text { Identification } \\
\left(\mathrm{X}_{1}\right)\end{array}$} & $\begin{array}{l}\text { Supporting the } \\
\text { company of the goal }\end{array}$ & $\mathrm{X}_{1.1}$ & 0.666 & Valid & \multirow{4}{*}{$\begin{array}{l}0.674 \\
\text { (Reliable) }\end{array}$} \\
\hline & $\begin{array}{l}\text { Protecting its } \\
\text { reputation }\end{array}$ & $X_{1.2}$ & 0.778 & Valid & \\
\hline & $\begin{array}{l}\text { Supporting } \\
\text { products }\end{array}$ & $\mathrm{X}_{1.3}$ & 0.677 & Valid & \\
\hline & Brand loyalty & $\mathrm{X}_{1.4}$ & 0.721 & Valid & \\
\hline \multirow{3}{*}{$\begin{array}{l}\text { Self Concept } \\
\text { Connection }\left(\mathrm{X}_{2}\right)\end{array}$} & Knowledge & $\mathrm{X}_{2.1}$ & 0.769 & Valid & \multirow{3}{*}{$\begin{array}{l}0.651 \\
\text { (Reliable) }\end{array}$} \\
\hline & Expectation & $\mathrm{X}_{2.2}$ & 0.777 & Valid & \\
\hline & Assessment & $\mathrm{X}_{2.3}$ & 0.759 & Valid & \\
\hline \multirow[t]{5}{*}{ Brand Love $\left(\mathrm{Y}_{1}\right)$} & Passion for a brand & $\mathrm{Y}_{1.1}$ & 0.750 & Valid & \multirow{5}{*}{$\begin{array}{l}0.779 \\
\text { (Reliable) }\end{array}$} \\
\hline & Brand attachment & $Y_{1.2}$ & 0.812 & Valid & \\
\hline & $\begin{array}{l}\text { Positive evaluation } \\
\text { of a brand }\end{array}$ & $\mathrm{Y}_{1.3}$ & 0.690 & Valid & \\
\hline & $\begin{array}{l}\text { Positive emotions in } \\
\text { response to the brand }\end{array}$ & $\mathrm{Y}_{1.4}$ & 0.745 & Valid & \\
\hline & $\begin{array}{l}\text { Declarations of love } \\
\text { toward the brand }\end{array}$ & $\mathrm{Y}_{1.5}$ & 0.635 & Valid & \\
\hline \multirow{3}{*}{$\begin{array}{l}\text { Brand } \\
\left(\mathrm{Y}_{2}\right)\end{array}$} & Behavior measures & $\mathrm{Y}_{2.1}$ & 0.812 & Valid & \multirow[b]{3}{*}{0.751} \\
\hline & $\begin{array}{l}\text { Measuring switch } \\
\text { cost }\end{array}$ & $\mathrm{Y}_{2.2}$ & 0.739 & Valid & \\
\hline & $\begin{array}{l}\text { Measuring } \\
\text { satisfaction }\end{array}$ & $Y_{2.3}$ & 0.698 & Valid & \\
\hline
\end{tabular}


PRIMANOMICS : JURNAL EKONOMI DAN BISNIS - VOL. 19. NO. 1 (2021)

Versi Online Tersedia di : https://jurnal.ubd.ac.id/index.php/ds | 1412-632X (Cetak) | 2614-6789 (Online) |

\begin{tabular}{|c|c|c|c|c|c|}
\hline Variable & Indicator & $\begin{array}{l}\text { Notatio } \\
\mathrm{n}\end{array}$ & $\begin{array}{l}\text { Koefisien } \\
\text { Korelasi } \\
\text { (r) }\end{array}$ & Validity & $\begin{array}{l}\text { Alpha } \\
\text { Cronbach } \\
\text { (Reabilitas) }\end{array}$ \\
\hline & $\begin{array}{l}\text { Measuring liking } \\
\text { brand }\end{array}$ & $\mathrm{Y}_{2.4}$ & 0.733 & Valid & (Reliable) \\
\hline & $\begin{array}{l}\text { Measuring } \\
\text { commitment }\end{array}$ & $Y_{2.5}$ & 0.540 & Valid & \\
\hline Source: & Data & processing & & results, & 2019. \\
\hline
\end{tabular}

Figure 1. Path diagram of the analysis results in sem

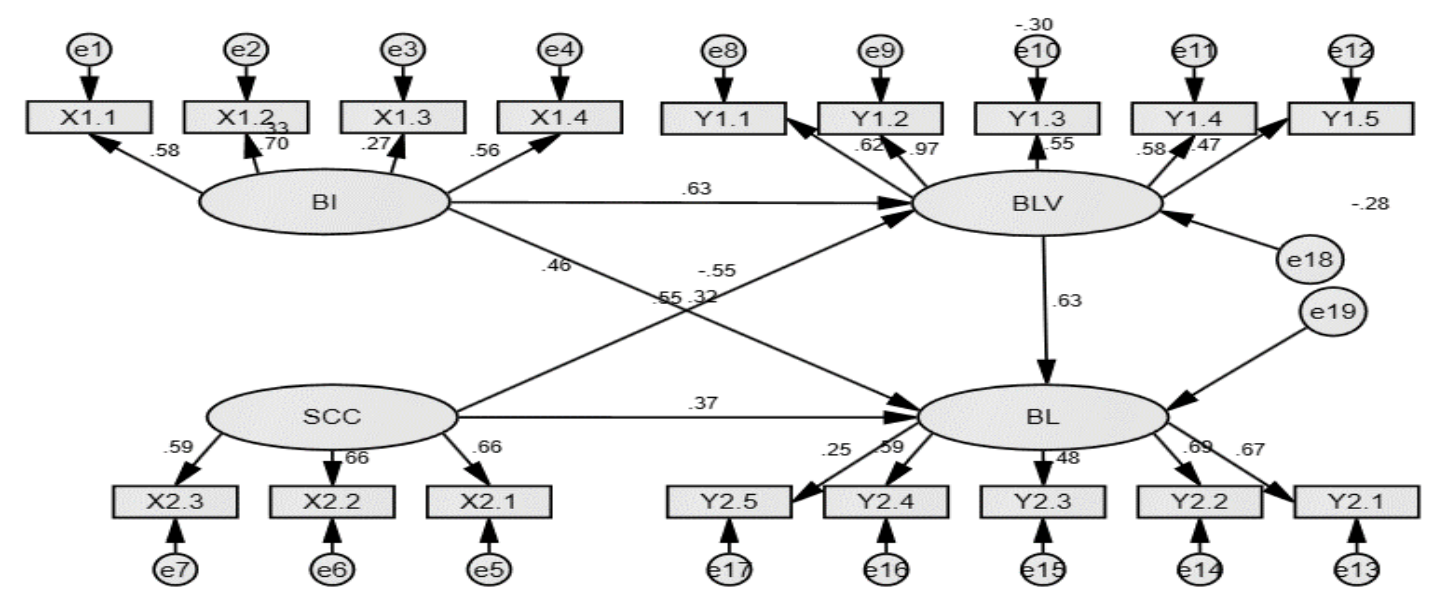


Source: Data Processing Results, 2019.

Fit model test results

Table 2. Results of the goodness of fit overall model test

\begin{tabular}{llll}
\hline Criteria & Cut-of-Value & Model Results & Information \\
\hline Chi-Square & Kecil & 116.552 & Model Fit \\
p-value & $\geq 0.05$ & 0.354 & Model Fit \\
CMIN/DF & $\leq 2.00$ & 1.488 & Model Fit \\
GFI & $\geq 0.90$ & 0.870 & Marginal Fit \\
AGFI & $\geq 0.90$ & 0.813 & Tidak Fit \\
TLI & $\geq 0.95$ & 0.890 & Tidak Fit \\
CFI & $\geq 0.95$ & 0.915 & Marginal Fit \\
RMSEA & $\leq 0.08$ & 0.070 & Model Fit \\
\hline
\end{tabular}

Source: Data Processing Results, 2019.

Based on the table above, it shows that the SEM used to test the causality relationship between variables in the model shows that this model is acceptable. Test there is a suitability of the model shows the results of testing the model fit close to the cut of value and declared model fit.

The loading factor value shows the weight of each indicator as a measure of each variable. Indicators with large loading factors are indicators as measuring the strongest (dominant) variable. The following is an explanation of the loading factors of each research variable as follows:

Table 3. Standardized Loading Factor

\begin{tabular}{|c|c|c|c|c|}
\hline Variable & & Items & $\begin{array}{ll}\text { Notation } & \text { Standardized } \\
& \text { Loading Factor }\end{array}$ & Inf. \\
\hline \multirow[t]{4}{*}{$\begin{array}{l}\text { Brand } \\
\text { Identification }\left(X_{1}\right)\end{array}$} & $\begin{array}{l}\text { Supporting the } \mathrm{X}_{1.1} \\
\text { company of the goal }\end{array}$ & 0.584 & \multirow{4}{*}{$\begin{array}{l}\text { The strongest } \\
X_{1.2}=0.704\end{array}$} & \\
\hline & $\begin{array}{lll}\begin{array}{l}\text { Protecting } \\
\text { reputation }\end{array} & \text { its } & \mathrm{X}_{1.2} \\
\end{array}$ & 0.704 & & \\
\hline & $\begin{array}{l}\text { Supporting } \\
\text { products }\end{array}$ & 0.268 & & \\
\hline & Brand loyalty & 0.564 & & \\
\hline \multirow{3}{*}{$\begin{array}{l}\text { Self-Concept } \\
\text { Connection }\left(X_{2}\right)\end{array}$} & Knowledge & 0.656 & \multirow{3}{*}{$\begin{array}{l}\text { The strongest } \\
X_{2.2}=0.657\end{array}$} & \\
\hline & Expectation & 0.657 & & \\
\hline & Assessement & 0.587 & & \\
\hline \multirow[t]{5}{*}{ Brand Love $\left(Y_{1}\right)$} & Passion for a brand & 0.621 & \multirow{5}{*}{$\begin{array}{l}\text { The strongest } \\
Y_{1.2}=0.971\end{array}$} & \\
\hline & Brand attachment & 0.971 & & \\
\hline & $\begin{array}{l}\text { Positive evaluation of } \mathrm{Y}_{1.3} \\
\text { a brand }\end{array}$ & 0.554 & & \\
\hline & $\begin{array}{l}\text { Positive emotions in } \mathrm{Y}_{1.4} \\
\text { response to the brand }\end{array}$ & 0.584 & & \\
\hline & $\begin{array}{l}\text { Declarations of love } \mathrm{Y}_{1.5} \\
\text { toward the brand }\end{array}$ & 0.472 & & \\
\hline \multirow{2}{*}{$\begin{array}{l}\text { Brand Loyalty } \\
\left(Y_{2}\right)\end{array}$} & Behavior measures $\quad \mathrm{Y}_{2.1}$ & 0.666 & \multirow{2}{*}{$\begin{array}{l}\text { Terkuat } \\
\mathrm{Y}_{2.2}=0.691\end{array}$} & \\
\hline & $\begin{array}{l}\text { Measuring } \quad \text { switch } \\
\text { cost }\end{array}$ & 0.691 & & \\
\hline
\end{tabular}




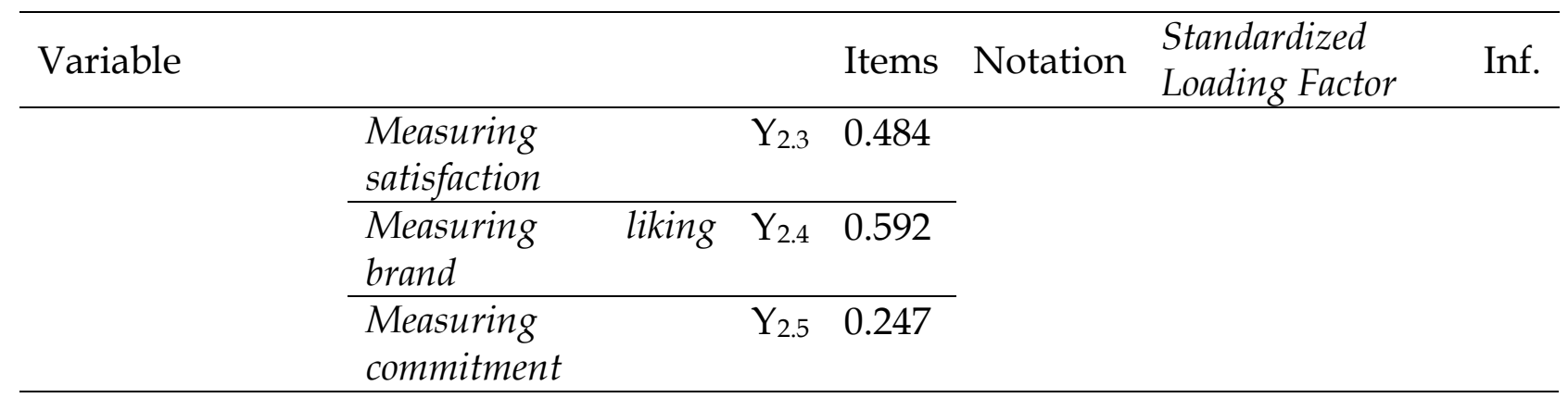

Source: Data Processing Results, 2019.

Based on the table above shows the loading factor value of each variable in this study. In the Brand Identification variable which has four indicators, the strongest indicator is Protecting its reputation (X1.2) with a loading factor of 0.704 , which means protecting the reputation of iPhone smartphone products in Samarinda City. In the Self-Concept Connection variable which has three indicators, the strongest indicator is Expectation (X2.2) with a loading factor value of 0.657 which means the desired expectation of using an iPhone brand smartphone in Samarinda City. In the Brand Love variable which has five indicators, the strongest indicator is the Brand attachment (Y1.2) with a loading factor value of 0.971 which means it has a feeling of bonding in using an iPhone brand smartphone in Samarinda City. In the Brand Loyalty variable which has five indicators, the strongest indicator is Measuring switch cost (Y2.2) with a loading factor value of 0.691, which means the attitude of customers in using the iPhone brand smartphone in Samarinda City is that the customer will still use the iPhone brand smartphone in the future. The influence of brand identification on brand love Based on the results of hypothesis testing discussed earlier, the first hypothesis is that it is suspected that Brand Identification has a positive and significant effect on Brand Love on iPhone brand smartphone users in Samarinda City, and it can be stated that the hypothesis is accepted because the results obtained are in accordance with the proposed hypothesis Brand Identification has a positive and significant effect on Brand Love. It said significant or not can be seen from the value of the Critical Ratio (C.R.) and seen from the Probability Value (P-Value).

Based on the calculation of the parameter coefficient between Brand Identification to Brand Love shows a significant effect of 0.670 , which means that the level of closeness between Brand Identification to Brand Love is $67 \%$.

Based on the statistical test results the Critical Ratio (CR) value of the Brand Identification variable against Brand Love is 3,645 greater than the critical value of \pm 1.96 determined from the table if a study uses more than 100 respondents. Significant results can also be seen from the probability value (p-value) of 0,000 which is smaller than the level of error (a) determined at $5 \%$ or 0.05 .

The Brand Identification variable has a significant effect on Brand Love for iPhone brand smartphone users in Samarinda City. This indicates that if the brand identification is very supportive of what is felt by the user, that is the greater the love for someone to use the iPhone brand smartphone in the city of Samarinda. This means that brand identification can occur without direct interaction between the company and consumers but only through products of the perception implanted by the company in the minds of consumers. 
The indicator that has the biggest Loading Factor of the Brand Identification variable is Protecting its reputation indicator with a value or weight of 0.704 greater than the error term of 0.5 . Indicates that the Protecting its reputation indicator has a truth level as a measure of the Brand Identification variable of $71 \%$ or higher than the error value, which means that the Brand Identification variable is reflected in the Protecting its reputation indicator and the variable affected is the Brand Love variable reflected in the Brand Attachment indicator with a value or weight of 0.971 is greater than the error term value of 0.5 . This indicates that the Brand Attachment indicator has a truth level as a measure of the Brand Love variable of $98 \%$.

Consumers with strong brand identification are more likely to protect their reputation, which will produce a sense of love for a brand on a product. This indicates that if a brand is well identified by consumers, it will raise the degree of the reputation of the company itself. Someone will state that a brand is the best item to be able to maintain the brand's reputation. The identification referred to here is everything that appears to describe the feeling of love for the brand itself. A good experience with a brand can provide an iPhone user identification with existing facilities in an iPhone smartphone such as features and applications available on the iPhone smartphone itself. Thus, they will decide to buy or use an iPhone in Samarinda City.

The results of this study are in line with previous research conducted, with the title "The Effects of Brand Image and Brand Identification on Brand Love and Purchase Decision Making: The Role of WOM". Get results that Brand Identification has a positive and significant influence on Brand Love. The same results were also found in a study conducted by (Rodrigues \& Reis, 2015), with the title "The Influence of" Brand Love "in Customer Behavior - The Case of Zara and Modalfa Brands". Get results that Brand Identification has a positive and significant influence on Brand Love.

Effect of self-concept connection on brand love

Based on the results of hypothesis testing discussed earlier, the second hypothesis is suspected that Self-Concept Connection has a positive and significant effect on Brand Love on iPhone brand smartphone users in Samarinda City, and it can be stated that the hypothesis is accepted because the results obtained are in accordance with the hypothesis proposed that the Self-Concept Connection has a positive and significant effect on Brand Love. It said significant or not can be seen from the value of the Critical Ratio (C.R.) and seen from the Probability Value (P-Value).

Based on the calculation of the parameter coefficient between Self-Concept Connection to Brand Love shows a significant effect of 0.479 which means that the level of closeness between Self-Concept Connection to Brand Love is $48 \%$.

Based on the statistical test results the Critical Ratio (CR) value of the Self-Concept Connection variable to Brand Love is 3,679 greater than the critical value of \pm 1.96 determined from the table if a study uses more than 100 respondents. Significant results can also be seen from a probability value ( $p$-value) of 0,000 which is smaller than the level of error (a) determined at $5 \%$ or 0.05 .

Variable Self-Concept Connection has a significant effect on Brand Love iPhone brand smartphone users in Samarinda City. This indicates that if there is a good self-concept relationship with iPhone users in Samarinda City, iPhone users will be more in love with deciding to use iPhone smartphone products. The perception picture of iPhone users feels that the iPhone brand can reflect their own very meaningful concept. 
The indicator that has the biggest Loading Factor from the Self-Concept Connection variable is the Expectation indicator with a value or weight of 0.657 greater than the error term value of 0.5. Indicates that the Expectation indicator has a level of truth as a measure of the Self-Concept Connection variable at $66 \%$ or higher than the error value which means that the Self-Concept Connection variable is reflected in the Expectation indicator and the variable affected is the Brand Love variable reflected in the Brand Attachment indicator with a value or weight of 0.971 is greater than the error term value of 0.5. This indicates that the Brand Attachment indicator has a truth level as a measure of the Brand Love variable of $98 \%$.

This expectation is the ideal self (ideal self) or the aspired self. Self ideals (self-ideal) consists of longing, aspirations, hopes, desires for ourselves, or become human as what we want or aspire to in the future, so that will foster a sense of love for a brand on a product. This is influenced by the number of respondents who are dominated by women, where emotions are always satisfied with what is obtained and despite the number of similar smartphone products such as Samsung, OPPO, Xiaomi, VIVO, Sony, ASUS, and Acer.

The results of this study are in line with previous research conducted by (Mira, Chupani, \& Panahandeh, 2014) with the title "Effect Brand Love and Self-Concept Connection on Brand Loyalty". Where this research supports the hypothesis that the Self-Concept Connection has a positive and significant effect on Brand Love. Likewise, research conducted by (Hwang \& Kandampully, 2012) with the title "The Role of Emotional Aspects in Younger Consumer-Brand Relationships". Get results that SelfConcept Connection has a positive and significant influence on Brand Love.

The effect of brand identification on brand loyalty

Based on the results of hypothesis testing discussed earlier, the third hypothesis is alleged that Brand Identification has a positive and significant effect on Brand Loyalty on iPhone brand smartphone users in Samarinda City, and it can be stated that the hypothesis is accepted because the results obtained are in accordance with the proposed hypothesis Brand Identification has a positive and significant effect on Brand Loyalty. It said significant or not can be seen from the value of the Critical Ratio (C.R.) and seen from the Probability Value (P-Value).

Based on the calculation of the parameter coefficient between Brand Identification to Brand Loyalty shows a significant effect of 0.347 which means that the level of closeness between Brand Identification to Brand Loyalty is 34\%.

Based on the statistical test results the Critical Ratio (CR) of the Brand Identification variable against Brand Loyalty is 1,910 greater than the critical value of \pm 1.96 determined from the table if a study uses more than 100 respondents. Significant results can also be seen from the probability value ( $p$-value) of 0.056 which is smaller than the level of error (a) determined at $5 \%$ or 0.05 .

The Brand Identification variable has a significant effect on Brand Loyalty of iPhone brand smartphone users in Samarinda City. This means that brand identification guarantees that someone will be loyal to use the iPhone brand smartphone in Samarinda City. This will affect the user's loyalty to the iPhone brand they have, which means that brand identification can occur without direct interaction between the 
company and consumers but only through the product of the perception implanted by the company in the minds of consumers.

The indicator that has the biggest Loading Factor of the Brand Identification variable is Protecting its reputation indicator with a value or weight of 0.704 greater than the error term of 0.5. Indicates that the Protecting its reputation indicator has a truth level as a measure of the Brand Identification variable of $71 \%$ or higher than the error value, which means that the Brand Identification variable is reflected in the Protecting its reputation indicator and the variable affected is the Brand Loyalty variable reflected in the Measuring Switch indicator Cost with a value or weight of 0.691 is greater than the error term value of 0.5 . This indicates that the Measuring Switch Cost indicator has a truth level as a measure of the Brand Loyalty variable by $70 \%$.

Consumers with strong brand identification are more likely to protect reputation, so that will produce a sense of loyalty to a brand on a product. The identification referred to here is everything that appears to describe the level of loyalty of the use of the iPhone brand. And associated with the characteristics of respondents based on gender and age, the greatest in this study are women and ages at 21 to 30 years so it can be concluded that there is a tendency to be loyal towards a smartphone brand and choose to continue to use and will make repeat purchases, whereas if viewed in terms of revenue that smartphone users who love the iPhone brand with an income of 2 to 4 million, it is very possible for users to repurchase the iPhone.

The results of this study are in line with previous studies conducted by Shirazi et al., (2013), with the title "Investigating the Effects of Brand Identity on Customer Loyalty from Social Identity Perspective". Where this research supports the hypothesis that Brand Identification has a positive and significant influence on Brand Loyalty. The same results were also found in a study conducted by (Rodrigues \& Reis, 2015), with the title "The Influence of" Brand Love "in Customer Behavior - The Case of Zara and Modalfa Brands". Get results that Brand Identification has a positive and significant influence on Brand Loyalty.

Effect of self-concept connection on brand loyalty

Based on the results of hypothesis testing discussed earlier, the fourth hypothesis is suspected that Self-Concept Connection has a positive and significant effect on Brand Loyalty on iPhone brand smartphone users in Samarinda City, and it can be stated that the hypothesis is accepted because the results obtained are in accordance with the hypothesis proposed that the Self-Concept Connection has a positive and significant effect on Brand Loyalty. It said significant or not can be seen from the value of the Critical Ratio (C.R.) and seen from the Probability Value (P-Value).

Based on the calculation of the parameter coefficient between Self-Concept Connection to Brand Love shows a significant effect of 0.323 which means that the level of closeness between Self-Concept Connection to Brand Love is 32\%.

Based on statistical test results the value of the Critical Ratio (CR) variable Self-Concept Connection for Brand Loyalty is 2,403 greater than the critical value of \pm 1.96 determined from the table if a study uses more than 100 respondents. Significant results can also be seen from a probability value ( $\mathrm{p}$-value) of 0.016 which is smaller than the level of error (a) determined at $5 \%$ or 0.05 .

The Self-Concept Connection variable significantly influences the Brand Loyalty of iPhone brand smartphone users in Samarinda City. This means that the higher the self- 
concept relationship felt by iPhone users, the higher the loyalty to use the iPhone brand smartphone in Samarinda. The self-concept of the brand here is the user's self-concept that the iPhone brand can be relied on in terms of performance, specifications, and the products offered. The perception picture of iPhone users feels that the iPhone brand can reflect their own very meaningful concept.

The indicator that has the biggest Loading Factor from the Self-Concept Connection variable is the Expectation indicator with a value or weight of 0.657 greater than the error term value of 0.5. Indicates that the Expectation indicator has a level of truth as a measure of the Self-Concept Connection variable at $66 \%$ or higher than the error value, which means that the Self-Concept Connection variable is reflected in the Expectation indicator and the variable affected is the Brand Loyalty variable reflected in the Measuring switch indicator cost with a value or weight of 0.691 is greater than the value of error term that is 0.5 . This indicates that the Measuring switch cost indicator has a truth level as a measure of the Brand Loyalty variable by $70 \%$.

This expectation is the ideal self (ideal self) or the aspired self. Self-ideal (self-ideal) consists of longing, aspirations, hopes, desires for ourselves, or become human as what we want or aspire to in the future so that it will foster loyalty towards a product brand. From the data of female respondents who dominate the study because when women have a self-concept relationship to a brand, it will cause an attitude of loyalty towards the brand and in the income of 2 to 4 million they are able to buy back with the same brand. If seen from the data of respondents with the category of self-concept relationship to the respondent's brand, the most dominant answer is to agree $(S)$. This means users have a self-concept relationship to the iPhone product.

The results of this study are in line with previous studies conducted by (Hwang \& Kandampully, 2012), with the title "The Role of Emotional Aspects in Younger Consumer-Brand Relationships". Get results that the Self-Concept Connection has a positive and significant influence on Brand Loyalty. Likewise. Where this research supports the hypothesis that the Self-Concept Connection has a positive and significant influence on Brand Loyalty.

The influence of brand love on brand loyalty

Based on the results of hypothesis testing discussed earlier, the fifth hypothesis is suspected that Brand Love has a positive and significant effect on Brand Loyalty on iPhone brand smartphone users in Samarinda City, and it can be stated that the hypothesis is accepted because the results obtained are in accordance with the proposed hypothesis. Brand Love has a positive and significant effect on Brand Loyalty. It said significant or not can be seen from the value of the Critical Ratio (C.R.) and seen from the Probability Value (P-Value).

Based on the calculation of the parameter coefficient between Brand Love and Brand Loyalty shows a significant effect of 0.625 , which means that the level of closeness between Brand Love and Brand Loyalty is $62 \%$.

Based on the statistical test results the Critical Ratio (CR) value of the Brand Love variable against Brand Loyalty is 2,789 greater than the critical value of \pm 1.96 determined from the table if a study uses more than 100 respondents. Significant results can also be seen from the probability value ( $p$-value) of 0.005 which is smaller than the level of error (a) determined at $5 \%$ or 0.05 . 
The Brand Love variable significantly influences the Brand Loyalty of iPhone brand smartphone users in Samarinda City. This means that brand identification guarantees that someone will be loyal to use the iPhone brand smartphone in Samarinda City. Users feel love for the smartphone brand and this love affects users who will be loyal to the iPhone brand they have.

The indicator that has the biggest Loading Factor of the Brand Love variable is the Brand Attachment indicator with a value or weight of 0.971 greater than the error term value of 0.5. Indicates that the Brand Attachment indicator has a level of truth as a measure of the Brand Love variable of $97 \%$ or higher than the error value which means that the Brand Love variable is reflected in the Brand Attachment indicator and the variable affected is the Brand Loyalty variable reflected in the Measuring Switch Cost indicator with value or weight of 0.691 is greater than the error term value of 0.5 . This indicates that the Measuring Switch Cost indicator has a truth level as a measure of the Brand Loyalty variable by $70 \%$.

Feeling bound to the brand will guarantee that users will be loyal to the iPhone brand and if analyzed from the data based on respondents in the category whether the respondent has a love for the product, the most dominant answer is the respondent says he agrees. This means that respondents have a love for the iPhone brand and affect the level of loyalty in using the iPhone brand. And associated with the characteristics of respondents by sex and age the greatest in this study are women and ages at 21 to 30 years so it can be concluded that there is an attitude that tends to be stable and not easily bored with a smartphone brand and chooses not to replace and will make a repurchase, and when viewed in terms of income smartphone users like the iPhone brand with a total income of 2 to 4 million, it is very possible for users to repurchase an iPhone with a higher series.

The results of this study are in line with previous research conducted by Mira et al., (2014), with the title "Effect Brand Love and Self-Concept Connection on Brand Loyalty". Where this research supports the hypothesis which says that Brand Love has a positive and significant influence on Brand Loyalty. Similarly, the results of research conducted by (Hwang \& Kandampully, 2012), with the title "The Role of Emotional Aspects in Younger Consumer-Brand Relationships". Get results that Brand Love has a positive and significant influence on Brand Loyalty.

\section{CONCLUSION}

Brand Identification has a significant effect on Brand Love iPhone brand smartphone users in Samarinda City. This means that the higher the brand identification (Brand Identification) of iPhone brand smartphone users, the greater the brand love (Brand Love) for someone to use an iPhone brand smartphone.

Self-Concept Connection has a significant effect on Brand Love iPhone brand smartphone users in Samarinda City. This means that the better the self-concept connection (Self-Concept Connection) of iPhone brand smartphone users, the greater the brand's love for someone using an iPhone brand smartphone.

Brand Identification has a significant effect on Brand Loyalty for iPhone brand smartphone users in Samarinda City. This means that the higher the brand identification (Brand Identification) of iPhone brand smartphone users, the higher the brand loyalty (Brand Loyalty) for someone to use an iPhone brand smartphone. 
Self-Concept Connection has a significant effect on Brand Loyalty of iPhone brand smartphone users in Samarinda City. This means that the better the self-concept connection (Self-Concept Connection) of iPhone brand smartphone users, the higher the brand loyalty (Brand Loyalty) for someone to use an iPhone brand smartphone.

Brand Love has a significant effect on Brand Loyalty for iPhone brand smartphone users in Samarinda. This means that the more brand love (Brand Love) iPhone brand smartphone users, the higher the brand loyalty (Brand Loyalty) someone to use the iPhone brand smartphone.

\section{REFERENCES}

Arnould, E. J., Price, L., \& Zinkhan, G. M. (2002). Consumers. McGraw-Hill/Irwin.

Brakus, J. J., Schmitt, B. H., \& Zarantonello, L. (2009). Brand experience: what is it? How is it measured? Does it affect loyalty? Journal of Marketing, 73(3), 52-68.

Büschken, J. (2004). Higher profits through customer lock-in: a roadmap. Thomson.

Carroll, B. A., \& Ahuvia, A. C. (2006). Some antecedents and outcomes of brand love. Marketing Letters, 17(2), 79-89.

Clara, C. (2019). CUSTOMER BRAND RELATIONSHIP: PERAN BRAND LOVE TERHADAP BRAND COMMITMENT DAN POSITIVE WORD OF MOUTH. Buletin Ekonomi Manajemen, Ekonomi Pembangunan, Akuntansi, 17(1).

Dick, A. S., \& Basu, K. (1994). Customer loyalty: toward an integrated conceptual framework. Journal of the Academy of Marketing Science, 22(2), 99-113.

Hwang, J., \& Kandampully, J. (2012). The role of emotional aspects in younger consumer-brand relationships. Journal of Product \& Brand Management, 21(2), 98108.

Keller, J. M. (1987). Development and use of the ARCS model of instructional design. Journal of Instructional Development, 10(3), 2.

Kotler, P., \& Keller, K. (2011). Marketing management 14th edition. Prentice Hall.

Mandel, N., \& Johnson, E. J. (2002). When web pages influence choice: Effects of visual primes on experts and novices. Journal of Consumer Research, 29(2), 235-245.

Meyers-Levy, J., \& Peracchio, L. A. (1995). Understanding the effects of color: How the correspondence between available and required resources affects attitudes. Journal of Consumer Research, 22(2), 121-138.

Mira, A., Chupani, S., \& Panahandeh, A. H. (2014). Effect Brand Love and Self-Concept Connection on Brand Loyalty. NATIONALPARK-FORSCHUNG IN DER SCHWEIZ (Switzerland Research Park Journal), 102(12).

O’Brien, L., \& Jones, C. (1995). Do rewards really create loyalty? Long Range Planning, 28(4), 130.

Oliver, R. L. (1999). Whence consumer loyalty? Journal of Marketing, 63(4_suppl1), 33-44.

Reichheld, F. F., Teal, T., \& Smith, D. K. (1996). The loyalty effect.

Rodrigues, J., \& Reis, H. (2015). Gestão Orçamental (2a Edição). Lisboa: Escolar Editora.

Veryzer Jr, R. W., \& Hutchinson, J. W. (1998). The influence of unity and prototypicality on aesthetic responses to new product designs. Journal of Consumer Research, 24(4), 374-394.

Wijayanti, I. D. S. (2008). Manajemen. Editor: Ari Setiawan. Yogyakarta: Mitra Cendikia. 